\title{
THE PLACE AND FUNCTIONS OF VOLUNTARY ASSOCIATIONS.
}

Introduction to exhibit of concrete institutions-Definition-Principles 0 classification-Prevalence in the United States-Four normal uses; satisfaction of local and transient needs, criticism, experimentation and supplementary action-Abuses-Prospect.

De Tocqueville wrote of a much neglected class of institutions: "Nothing, in my opinion, is more deserving of our attention than the intellectual and moral associations of America. The political and industrial associations of that country strike us forcibly, but the others elude our observation, or, if we discover them, we understand them imperfectly, because we have hardly ever seen anything of the kind. It must, however, be acknowledged that they are as necessary to the American people as the former, and perhaps more so.

"In democratic countries the science of association is the mother of science; the progress of all the rest depends upon the progress it has made.

"Among the laws which rule human societies there is one which seems to be more precise and clear than all others. If men are to remain civilized, or to become so, the art of associating together must grow and improve in the same ratio in which the equality of conditions is increased."'x

It is a part of the plan of this journal to publish descriptions, estimates and criticisms of many forms of free coöperation for human ends. The theorist and the practical man are alike bewildered by the teeming variety of organizations which solicit attention and funds. It is believed that brief but adequate treatment of various typical agencies of amelioration and satisfaction may prove helpful in fixing the rank of conflicting and clamor-

${ }^{\prime}$ 'The place and value of the voluntary association are recognized by Schäfle, Bau und Leben, Bnd. I., S. 740, ff.; A. de Tocqueville, Democracy in America, Vol. I., p. 204, and Vol. II., p. II8, 4th Amer. ed., I84I; Bryce, American Commonwealth, Vol. II., p. 239, Macmillan \& Co., I889. 
ous societies which ask the time and funds of thinkers and philanthropists.

In America there are no legal restrictions on the formation of such bodies, and our laws even favor their multiplication and facilitate their incorporation. The only defense of a longsuffering public is publicity and criticism.

The family is not a voluntary association in the sense of the word here employed. Each human being becomes a member of the domestic institution by birth and not by choice, and at the age when reflection begins he discovers that this institution has already done its work upon him. The marriage contract is, indeed, relatively free, but the form of the union is determined partly by the elementary impulses of nature and the facts of sex and partly by the customs and laws through which society enforces its beliefs respecting the conditions of the common welfare.

Industrial organization is, in the main, determined by nature, general custom and legislation, and it changes very slowly in response to the movements of events and the devices of reformers. Men may freely form contractual partnerships or buy stock in corporations, but once in the toils of an agreement the range of their movements is quite distinctly marked out by law.

The church is an institution whose rigidity and conservatism are proverbial. Devotees boast that she never changes and doubters stigmatize her as a fossil. The golden medium is nearer the truth. The church is like all other institutions which have a vast range of movement in time and space and a long life; she grows, but must be rooted deeply in order to resist frost and drought and to abide the storms. The church is not an organization which can readily be made over by the combined efforts of a small circle of advanced thinkers.

The state is not a voluntary organization based on contract and formed by a convention. It is a growth, and all ages past have contributed threads for its warp and woof. All its citizens are born to its rights and obligations or pass into its life from without by solemn process of adoption and naturalization. 
The term "voluntary association" is here used to designate that form of social coöperation in which the conscious choice of each member determines his membership. It is true that all organizations, even those which are most free, are influenced by the fixed material conditions and the established customs and laws of a given community. But in these associations the selfdetermining element is most conspicuous and characteristic. Such a social organization is usually less permanent and rigid, and its membership more fluctuating and unstable than is true of the great and recognized institutions, such as the family, state and church.

They are created to serve many and varied ends. They may be organized in order to gain some special object or in order to change and direct the workings of the established institutions. They may be compared to the tenders which ply between the port and the great ships which are more at home on the deep sea than in the shallow harbor; or to the skirmish lines which are thrown out in advance of the main army.

It is bewildering to contemplate the clubs, societies, guilds, associations, unions, companies, congresses, fraternities, sodalities and lodges which figure in city directories and in the society columns of newspapers. In order to understand them we must seek some rational principles of classification and of judgment.

One mode of classification is based on the status of persons whose welfare is to be promoted. Thus we might have three groups of associations, philanthropic, mutual benefit and public. Goethe has given us the allegory of the Three Reverences, reverence for our peers, for the objects of our pity and for our superiors. But it seems better to employ this distinction to fix the boundaries of subgroups or species of association whose genera are otherwise marked.

Societies which coöperate with domestic, economic, educational, political and ecclesiastical bodies have the generic characters of the institutions to which they are most nearly related. But any method of classification must come short of representing the complexity of social relations. There are advantages in treating the same phenomena under different heads, because in 
this way the reciprocal and involved relations are more adequately realized.

Criteria of judgment must accompany principles of classification. It is natural, first of all, to inquire the purpose of the association. The final cause is here the creative force and the measure of worth. Usually the professed purpose is stated and published in the constitution. But the real ends may be much more complicated than the organic articles imply, and they may not correspond to published statements. Some of the earlier trades unions were organized under the title of friendly societies and mutual benefit clubs, because in no other way would public sentiment and law permit them to exist. Certain fashionable clubs have very attractive references to literature and art in their organic law; but the cook and bartender would be able to write a very instructive commentary on the public documents of the society. The final cause of a society must be sought in its conduct as well as in its verbal professions.

It is next necessary to set a value upon the purpose thus discovered. What satisfactions does it promise? How will realization of the aim affect society at large? How wide a range of persons is to receive help from it? In some cases, as college fraternities, much depends upon the character of the membership. Where financial elements are to be considered, the ability, capacity and fidelity of the officers are material considerations. Statistical science and art can here render valuable service as an ally by showing the geographical distribution, the fluctuations and tendencies, the successes and failures of various associations under consideration. The numerous "benevolent societies" of our country need this sort of examination, and the interests of millions of workingmen are involved in the investigation.

We turn to some of the normal uses of this form of social organization, and mention first the satisfaction of transitory wants of society or the needs of a local group or of a limited class. Differentiation carries with it variation of tastes. We must expect with higher civilization a growing unlikeness of aptitudes and inclinations. People who like the same things 
drift together. Sumptuary "blue laws" have never been able to suppress these differences, and experience has taught modern men that only in case of antagonism with the general welfare is it safe or just to control the methods of satisfaction of the various groups of a community. The ponderous machinery of government is too awkward to regulate the styles of bonnets, the rules of ball games and the number of wheels on vehicles. The permanent and universal needs may be met by state or municipality, but the criticism of Dante is best left to select circles. It would hardly be thought advisable to elect a congress for the settlement of the merits of Browning or of the higher criticism of the Bible. In fact even the larger ecclesiastical bodies make but little headway on such delicate matters. The army quartermasters can supply beans and bacon, but private enterprise must select the delicacies; and the Christian Commission was welcomed by the regular corps of surgeons as an indispensable aid during the Civil War.

Another normal use of the voluntary association is the development and application of a criticism of established customs and institutions. It is not reasonable to expect all the members of a great people to move forward at an equal pace. The highest peaks are flooded with the light of dawn while the valleys remain dark with the shadows of night. Columbus made it easy to cross the Atlantic, but it was not easy for him. The older abolitionists worked out a theory of a "higher law," an ideal of a better social conduct, and they condemned constitutions and decisions of gowned judges in the light of that law. They shamed the majority by contrasting fact with truth. In new and uncultivated communities clubs of women are slowly learning and teaching the first lessons of æsthetic culture. If they waited for town councils to act, under the control of rude democratic majorities and uneducated boards of education, our western cities would remain barbarian for another century. There is a "tendency in all things to sag," and the people of each generation are girded and braced for new journeys only by the prophetic discoveries and appeals of inspired leaders. And as the timber for martyrs is not found in every township we 
must be grateful to those who cheer the timid essays of groping minds by uniting the foremost men in companies of pioneers. Church and state would perish, and even good customs would corrupt the world if we did not have associations of selfappointed censors to disturb our complacency and goad us to reflection. But even martyrs and prophets have their fainting fits and sink down under a sense of loneliness, as we see in the case of the bold Elijah. Two are more than twice as brave as one, and a man on a committee of the Civic Federation feels strong even before a spoils politician. And then prophets have other weaknesses which need the correction of association. Reformers most of all men require the balance and brake of counsel. They are prone to forget, in sanguine moments, that the first question to settle is not how to do a thing but whether a thing should be done. Social doctors must sometimes be urged to study anatomy with the help of cadavers and cats before they indulge in vivisection on palpitating human beings. It is desirable that people with a strong reforming zeal should at least debate in companies of ten up to the point of agreement before they ask for legislation which involves sixty millions of people. A debating society has a fine field for suppressing raw social schemes, and this is one of its normal functions.

After discussion comes experimentation. It is wise to let an adventurous Stanley survey the Dark Continent before we send capital and colonies into the malarial coast. Our government has set up many experiment stations for the benefit of farmers, but groups of farmers have themselves tried new methods. If they fail only a few persons have suffered, and when they succeed all the world is wiser. In the administration of relief a local benevolent society can test methods which may, at a later stage, be found available for a province or an empire. The Workmen's Colonies of Germany have been developed by the efforts of small groups of generous people, and their utility and limitations have been discovered. It now seems probable that they will gradually come to be supported and controlled by the political authorities. They seem to have become too great for private 
funds to support and too valuable to abandon. The voluntary association seems the best form of social organization for research work in science and philosophy. It is free from the obstructive and obscurantist tendencies which seem inherent in all historic bodies. The interests of political and ecclesiastical parties and the prepossessions of officeholders rage around them in vain.

The voluntary association is often able to supply personal service where the mechanical methods of the state or the church are at fault. The Elberfeld system of poor relief is a good illustration. This system was established by the efforts of a representative of political and a representative of ecclesiastical organization, a magistrate and a pastor. It was found that municipal authorities could raise adequate funds and keep accounts and punish vagrants far better than benevolent societies. But when it came to a question of visiting the sick, bringing to them the cheer of friendship and the personal counsel of experience, sharing the riches of the sagacious with the witless and discouraged, the machinery of the state was too coarse and heavy. The army of bureaucrats confessed their defect and called to their assistance the friendly visitors who work for honor and for gratitude. Complete as is the system of communal relief it still leaves room for many forms of benevolence under the leadership of private persons.

There are many groups of voluntary associations more or less closely connected with the churches. The Y. M. C. A., the Christian Endeavor societies and the Christian Citizenship League are examples. It is sometimes said that the existence of these societies is a reproach to the church and an evidence of its failure. The criticism should not be hastily accepted. Such organizations rather imply that a considerable number of the members of the churches are ready to unite in a method of social amelioration for which there exists no suitable machinery. It is unreasonable to expect all the members of a body of four or five million members to rent the use of their vast and costly governmental plant for some local or temporary purpose, however worthy it may be. The voluntary association furnishes exactly the form of coöperation most desirable in these circumstances. 
There is a very powerful current of public opinion setting in the direction of state monopoly of many social functions, and there is another current opposed to such extension of political agency. These two tendencies will not suppress each other but will correct each other. Even when the city or state has undertaken a social function it is found that vigilant citizens must unite to watch the administration of a law. No popular government has yet solved the problem of perpetual motion. No people can have a pure, strong and effective government where there are no societies or parties to instruct the public, to expose corruption, and to investigate the manner in which officers treat the trusts committed to their care.

It may be thought that these voluntary associations are impertinent and pretentious. They seem to imply that their members profess to be more pious, intelligent and patriotic than their neighbors. The danger is real but it must be risked, and most of us can admit without jealousy the merits of any body of persons who will make life and property more secure and who lower our taxes.

It is said that these societies dissipate social energy, rival the home, sap the resources of the church and multiply like a plague of locusts. Unquestionably the objection is partly justified by facts. There are too many societies, especially too many bad ones. They overlap, duplicate and interfere with each other. Some of them seem to be organized simply to advertise the benevolence of the executive committee or furnish a stipend for a secretary. The business man is vexed and preplexed to know which society is worthy of his gifts and which deserves his curses.

But the severest judgment of an abuse leaves the normal use untouched. The voluntary associations require criticism and regulation, but the principle of their life is legitimate. In their best estate they are the indispensable means of innocent and wholesome gratifications, the pioneers of progress, the guardians of dearly-bought agencies of research and culture.

C. R. Henderson.

The University of Chicago. 